\title{
关于施工现场管理的优化策略
}

\author{
刘耀伦 \\ 中交一航局房地产开发有限公司 \\ DOI:10.18686/bd.v2i9.1656
}

[摘要] 伴随着经济的高速发展, 社会的不断变迁, 人们生活水平的不断提高, 施工建筑工程项目也随之增加。也因而出现 了很多施工现场管理的问题,如果这些问题一直得不到处理和控制, 必然会导致建筑施工项目的整体的质量和效率, 还会影 响社会的持续稳定发展, 从而延缓整个社会的发展脚步。在这个知识和经济主导的时代,一个施工建筑企业如果有很好的建 筑施工技术和较高的现场管理水平必然可以在竞争很激烈的建筑市场上取得一席之地, 获得更大的经济效益。

[关键词] 建筑工程; 建筑施工; 现场施工; 优化策略

\section{1 土建工程施工概述}

自步人 21 世纪之后,城市现代化的进程不断发展推进, 在现代化城市的建设中, 建筑最突出的特点就是高楼大厦。 建筑的高速发展提高了建筑行业的施工水平, 推进了建筑 行业的兴起和发展。但是,伴随着高速发展的同时,建筑施工 也相应出现了一些问题, 人们对施工技术有了更高的要求。 我国现在已经对建筑施工提出了更具体的要求, 颁发公布 了一系列的制度条例。现代的建筑施工需要多参考借鉴西 方先进的施工管理经验, 根据我国现在建筑施工的实际情 况, 制定与实际相符的建筑施工的规范, 也还需要进行科学 的工程招标和投标制定以及施工监督、施工合同制度,保证 施工的质量和安全。但是仍有一部分建筑企业为了获取更 高额的利润, 无视规定和制度, 不按照规定进行施工建设, 导 致出现不同程度的施工安全事故, 这严重抑制了建筑行业 的发展。

建筑的特征是整体结构高度比较大、类型复杂多变, 这 就要求施工企业应该具备比较高的技术水平, 和一般的建 筑结构比起来,施工难度要更大。所以,结构设计直接影响了 施工的质量,对建筑的施工的进行是一个很大的挑战。在对 建筑进行设计的时候,应该要遵循使用安全、经济合理的结 构原则, 施工的技术也要达到要求的标准水平, 确保建筑的 安全和质量。

此外, 建筑施工的时候使用的建筑材料种类和数量比 较多, 而且消耗的时间比较长。由于整个建筑整体结很大,十 分容易受到自然条件的干扰和影响。所以在建筑施工的过 程当中,应该合理科学地应用技术和措施。

\section{2 土建施工现场管理的现状}

2.1 现场监督管理的力度松散

工程质量是整个建筑工程中的基础, 直接影响整个建 筑行业的发展和进步。建筑施工现场经常由于现场监管力 度不到位, 导致施工质量不达标。工作人员不经批准私自改 动设计图纸、使用劣质不合格的建筑材料等问题频频出现, 这些直接导致施工的安全得不到保障,施工的质量不合格。 所以, 建筑施工的管理水平低下直接导致了建筑的安全和
质量得不到保证。除此之外, 因为建筑施工工程需要十分多 的劳动力, 需要大家互相协作来完成, 但是工作人员间所接 受的文化教育程度不一样,加大了现场管理问题的难度。有 相当一部分的监督管理人员在遇到难题的时候会畏首畏 脑, 犹豫不前, 监督管理的力度不够。再者就是工作人员对工 具和材料的放置存储混乱, 因为监管力度不够, 工作人员态 度比较懒散, 在工具放置和材料使用上也不按照规定, 纪律 差,工作人员懒散放松,十分随意。

2.2 施工人员的素质不高, 缺乏专业的技术人员

在目前这个阶段, 建筑工程这个行业的发展是很有前 景而且发展速度很快的, 建筑工程企业对员工的需求是很 大的, 所以, 为了获得更多的劳动力, 很大建筑企业单位对员 工的素质要求和技术要求就降低了。这直接造成了在工程 建筑的时候工人的综合素质过低, 而且, 很多的企业在员工 培训方面做的不到位, 忽视了员工的技术培训工作的重要 性, 致使员工的素质技术同社会上对建筑的要求不匹配,跟 不上时代的脚步和发展, 这就对建筑工程的施工造成了不 可忽视的影响。当下的建筑工程人员大部分都是没有受到 专业培训的农民, 具备专业的建筑工程证书和受到专业的 建筑教育的人员十分稀少, 施工现场管理的专业人员十分 的短缺。所以,建筑工程施工人员素质不到位是一个十分普 遍的现象, 这个现象直接造成了施工现场管理的水平低下, 工程的质量和安全得不到保证, 阻碍工程建筑的发展和进 步。

\section{3 施工的技术问题}

在建筑施工管理进行的过程当中, 施工人员的技术是 特别重要的, 施工工作的正常进行, 需要许多施工人员的共 同协作和努力,因此,这些工作人员必须要具备一定的专业 能力和知识技能。在当下形势来看, 我国的建筑施工企业和 单位对施工的技术和员工的综合素质并不重视, 而且有一 些员工都无法正确地使用建筑工程设备、对施工设备的存 放不细致,对设备也不会进行定期的检查和维修,这些问题 都会影响施工的质量效率和安全。

2.4 对环境造成污染 
建筑施工需要大量而且种类繁杂的建筑材料, 在进行 施工的时候会有许多的建筑垃圾出现, 并且有的时候为了 赶进度,建筑机器设备会日夜运作造成声音污染, 影响周边 居民,这就产生了一定的环境污染。

\section{3 优化改进策略}

3.1 加强施工现场的监督管理力度

第一:在施工的方面,需要依据工地的实际环境和状况 设计施工的方案,这是加强施工现场管理的基本需要。施工 方案是建筑施工的科学依据, 对建筑施工有指导的作用, 它 对各个技术的指标要求都有记录。施工管理监督人员可以 根据这个方案对施工现场的机器设备和工作人员进行合理 严格的管理。

第二: 建筑施工现场的监督管理人员应该对工作人员 进行组织管理, 严格工程过程中的纪律, 奖常有度。对违反规 定和纪律的员工,必须给予惩罚,使他们端正态度,认真仔细 对待工作,保证施工的安全和质量。

最后, 建筑工程的监督管理也包括现场的机器设备和 材料, 机器设备和材料对施工的安全和质量有很大的影响。 所以, 现场监督管理人员必须加强对机器设备正确使用和 材料合格的监督,让工作人员正确使用机器设备,保证原材 料的安全可靠性, 尤其是在当下许多仿冒和违规材料泛滥 的情况下, 一定要认真仔细谨慎地选择材料。对机器设备也 要做好定期的检查和维修,保证其正常运转。

3.2 提高施工人员的综合素质,引进专业的技术人员

施工人员的综合素质和技能知识直接影响建筑工程的 质量和效率,和建筑企业单位的发展和进步有很大的关联。 因此, 建筑公司应当积极培育引进高技术高素质的工程人 员,注重对在职员工的培训,提高员工的综合素质,进而使自 己的公司企业得到长久的发展和进步。定期对在职的施工 人员进行专业技术培训, 在进行招工的时候要对应聘者进 行审核, 宁缺冉滥。对新人进行前期的教育培训也很重要。 积极引进和招聘高级工程建筑师, 提升自己建筑队伍的质 量。

3.3 加强施工现场的操作技术

施工现场管理人员应该对施工现场的操作技术提起重 视,应当定期的对现场的施工操作技术进行检查和改善。仅 仅依靠施工现场的管理人员进行监督是不够的, 应当设立 一套更加全面的监督机制,不断完善监督管理的措施。施工 人员相互监督相互促进,规范施工的操作,降低因为施工操
作不当造成的安全事故的发生几率, 保证施工过程中的安 全性。对施工人员加强培训, 有针对性进行培训, 根据实际的 情况进行员工培训,提高员工的操作技术和能力。

\section{4 加强施工现场的环境保护}

在当下,环保这是我们国家一直强调的问题,因为建筑 工程的特性,所以在施工的过程中必须做好环境保护,尽可 能地将污染降到最小,积极响应国家的政策条例,紧跟时代 的步伐,实现持续稳定的发展。比如,建筑工程中产生的建筑 垃圾不能同普通的垃圾一样随意处理, 务必要将其运送到 规定的地方, 定期进行处理。建筑施工尽量在白天进行, 不能 影响居民的生活休息,倘若特殊的情况需要,应当和附近的 居民进行协调沟通,交流之后再工作。

\section{5 加强施工现场的安全管理}

在进行建筑施工的过程当中, 加大建筑施工管理的力 度, 可以保证建筑施工的安全质量和施工效率。所以,必须要 制定一系列的科学合理的管理体系, 对建筑施工过程中的 各个环节各个项目进行分别管理和监督, 提升建筑施工的 安全性。并且还要对施工工作人员进行安全教育, 提高工作 人员的安全意识,规范工作人员的行为。在施工过程中出现 问题,应当及时记录并探讨分析,及时解决问题,不能任由问 题发展下去。只有严格地进行现场的施工管理,才能保证施 工的质量和安全。

\section{4 结束语}

施工现场的管理工作使建筑施工的重要组成部分之 一, 它关系到施工的安全和质量,关系到公司的经济效益和 发展。直接影响后期建筑的质量, 将施工现场的管理工作做 好, 是对企业利益、建筑的质量和施工安全的保证。所以建 筑施工管理人员一定要加强监督管理的力度, 严格监督施 工现场的管理,保证施工的安全性, 高效率地完成建筑施工 工作。提高施工质量, 推动建筑施工行业的持续稳定的发 展。

\section{[参考文献]}

[1]陈晖辉.建筑工程土建施工现场管理的优化策略探 讨[J].建材与装饰,2018,(08):121-122.

[2] 杨超杰. 建筑工程土建施工现场管理的优化策略 [J].山西建筑,2018,44(06):249-250.

[3]王晓鸠.浅谈土建工程施工现场管理模式的优化策 略和改进措施[J].建材与装饰,2018,(06):210. 